\title{
Prevalence of and Risk Factors for Sexual Victimization In College Women in Chile
}

By Jocelyn A. Lehrer, Vivian L. Lehrer, Evelyn L. Lehrer and Pamela B. Oyarzún

Jocelyn A. Lehrer is senior research associate, Bixby Center for Reproductive Health Research and Policy, University of California, San Francisco, USA. Vivian L. Lehrer is Equal Justice Works Fellow, Urban Justice Center, Domestic

Violence Project, New

York. Evelyn L. Lehrer is professor, Department of Economics,

University of Illinois at Chicago, USA.

Pamela B. Oyarzún is assistant professor, Center for Reproductive Medicine and Adolescent Health, School of Medicine, University of Chile, Santiago.

\begin{abstract}
CONTEXT: To date, no quantitative studies have examined the prevalence or correlates of sexual violence among col-
\end{abstract} lege students in Chile.

METHODS: An anonymous survey with questions on gender-based violence, demographic and socioeconomic characteristics, and childhood experiences with violence was administered to students at a major public university in Santiago. Descriptive statistics were generated to determine the prevalence and context of sexual victimization experienced by female students, and ordered logit models were used to identify associated risk factors.

RESULTS: Nine percent of subjects reported that the most severe form of undesired sexual contact they had experienced since age 14 was rape; $6 \%$ indicated attempted rape and $16 \%$ another form of sexual victimization. Seventeen percent of subjects reported having experienced some form of undesired sexual contact in the past 12 months alone. Alcohol or other drugs had been used in most cases of rape or attempted rape, by the victim (6\%), the perpetrator (9\%) or both (56\%). In four sequential models, factors associated with increased odds of victimization included low parental education (Model 1) and childhood sexual abuse (Models 3 and 4); the association between witnessing domestic violence and victimization attained marginal significance (Model 2). Attending religious services during adolescence was associated with reduced odds of victimization (Models 1 and 2). Childhood sexual abuse was the only factor associated with victimization when all variables were included.

CONCLUSIONS: A substantial proportion of young women in the sample reported experiences of rape, attempted rape or other forms of forced sexual contact, indicating a need for further attention to this public health problem in Chile. International Family Planning Perspectives, 2007, 33(4):168-175

Recent studies have documented a high level of gender-based violence in Chile and other Latin American countries. ${ }^{1-7}$ Although there have been some exceptions, ${ }^{8,9}$ most of the research to date has focused on violence against women within the context of cohabitation or marriage. ${ }^{10}$ Substantially less is known about gender-based violence perpetrated against adolescent and young adult women. This is a concern, as previous research has shown that experiencing sexual victimization during late adolescence or young adulthood can have far-reaching consequences, including unwanted pregnancy and increased risk of psychological, sexual and reproductive health problems. ${ }^{11-13}$ In addition, analyses conducted in developing countries have found that experiences of sexual violence can limit young women's ability to achieve their educational potential. ${ }^{14}$

The present study focused on college students. Approximately $46 \%$ of youth aged 20-24 in Chile are enrolled in an institution of higher education. ${ }^{15}$ No published quantitative studies have examined dating violence or sexual assault in this population, and campuses across the country lack systematized programs to prevent or respond to these problems.

* In additional studies, currently in progress, we are analyzing other data collected in this survey, including women's experiences of physical and psychological dating violence.
To begin to address this gap in knowledge, we developed the 2005 Survey of Student Well-Being. Administered to male and female students at a large public university in Chile, the survey included questions on experiences with sexual victimization within or outside the context of dating relationships, and with physical and psychological dating violence. The survey also included questions on rape myth acceptance, childhood sexual abuse, witnessing of violence between parents, and socioeconomic and demographic characteristics. The purpose of the present study was to examine the prevalence of and risk factors for sexual victimization in the female sample, the extent of women's rape myth acceptance and the contexts of sexual assault. * Our analysis was guided by the numerous U.S. studies that have examined factors associated with young women's vulnerability to sexual assault, with the purpose of helping in the design of effective risk-reduction programs and in the provision of clinically useful information to health practitioners. ${ }^{11,16-18}$

In assessing risk factors, we considered two primary domains: childhood experiences with violence, and socioeconomic and demographic factors. There is some evidence that witnessing domestic violence during childhood may increase vulnerability to subsequent sexual victimization. ${ }^{19}$ The evidence with regard to early experiences of sexual abuse is stronger: Both retrospective and prospective stud- 
ies of U.S. college students have found a positive association between sexual abuse during childhood or adolescence and sexual revictimization later in life. ${ }^{19-21}$ It has been suggested that this association partly reflects psychological sequelae of childhood sexual abuse (e.g., negative self-image, depression, learned helplessness) and resulting behavioral manifestations (e.g., substance abuse, multiple sexual partners). ${ }^{17,22,23}$

Such abuse is by no means rare, although estimates of prevalence vary: A study of 19 countries around the world found that $7-36 \%$ of women reported having been sexually abused during childhood. ${ }^{24}$ Wide ranges in prevalence have also been reported in other research and have been attributed to differences across studies in the upper age limit used in the definition of childhood, the types of behaviors included in the definition of abuse and the composition of the study samples. ${ }^{25}$ Differences in reporting methods and the anonymity of responses may also play a role. Although data for Latin America are scarce, a recent study in urban areas of Peru found a prevalence of sexual abuse by age 15 of $19-20 \%$ (depending on the reporting method used). ${ }^{7}$

Our study also examined possible associations between sexual victimization and various socioeconomic and demographic factors. While research findings are mixed, several studies in the United States and Latin America suggest that youth who live in socioeconomically disadvantaged households are more likely than those in more privileged

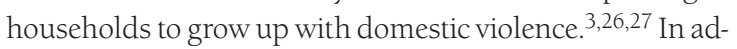
dition, low socioeconomic status has been linked to a higher prevalence of childhood sexual abuse, although this association may in part reflect the greater ease of detecting such abuse in lower-income groups. ${ }^{28}$ To the extent that low socioeconomic status is associated with a heightened risk of early experiences with these forms of violence, there may be a resulting indirect link between low socioeconomic status and increased vulnerability to sexual victimization later in life.

Another factor that may be relevant to the risk of sexual victimization is religiosity. Young people raised with some participation in religious activities tend to engage in fewer risk behaviors, including use of alcohol and other drugs, 29,30 and are more likely to have friends who do not use substances, ${ }^{31}$ compared with youth who grow up with no involvement in religious activities. These patterns may partly account for findings that link religious participation to a lower risk of physical dating violence victimization. ${ }^{32-34}$ For similar reasons, religiosity may be associated with a reduced risk of sexual victimization.

Initiating sexual activity at a young age and having multiple sex partners have each been associated with a heightened risk of sexual victimization, results that have been interpreted within a situational vulnerability framework-i.e., these behaviors may increase exposure to potential aggressors. ${ }^{16,17,35,36}$ Although youths' living arrangements have received little attention in the literature, they may also be associated with victimization risk; college students who live independently are likely to be more vulnerable than their counterparts who reside with their parents. Finally, place of residence (urban vs. rural) may affect exposure to risk, but results to date, based on studies of high school students, have been mixed. ${ }^{37,38}$

\section{METHODOLOGY Study Design}

The survey instrument, a closed-ended questionnaire, was compiled in English by the lead author and translated into Spanish by the third author, a Chilean native. To ensure accuracy, the questionnaire was back-translated into English. Most of the items were adapted to the Chilean social context from scales validated in the U.S. and other countries, and were revised further based on comments from professors and students at the participating university regarding content, cultural appropriateness and wording. The second author conducted the fieldwork after the project was approved by the university's Ethics Committee for Research on Human Subjects.

The university, which is located in Santiago, is one of the largest and most prestigious in Chile, and enrolls students from diverse socioeconomic backgrounds. University officials demonstrated strong interest in participating in this research project and allowed us to administer the survey to students in the 25 general education courses offered during the winter of 2005. We surveyed students in all of these courses, except for one that was affected by class cancellation. The resulting sample included male and female students enrolled in all of the university's educational programs. Total enrollment in the 24 courses was 2,451, although the number of individual students was somewhat smaller because some students were taking more than one course. At the time of survey administration, which took place over several weeks, 1,193 students were present in the 24 classes, consistent with typical attendance in general education courses at the university; 970 students returned completed surveys, reflecting an $81 \%$ response rate. Students who had already completed the questionnaire in another class were instructed not to do so again, accounting for some of the nonresponses.

To introduce the study, the survey administrator explained its nature and relevance, noted that the questionnaire included sensitive items on experiences of sexual, physical and psychological violence, and emphasized that all responses would be anonymous. Students provided written consent prior to completing the survey and deposited their completed, unsigned questionnaires in a box placed at the front of the room. Professors were absent during survey administration.

The final survey item asked subjects to indicate how honest their responses had generally been. The questionnaires of two subjects who reported not providing honest responses were excluded, as were those of two other students whose responses indicated that they had not taken the survey seriously. Sixteen additional cases with missing data on student's sex were eliminated, yielding a base sample of 484 women and 466 men. The present study used the 
female sample. After we eliminated 26 cases with missing data on sexual victimization since age 14 (the outcome variable) and three cases with four or more missing items in the 10-item rape myth scale, the final study sample had 455 subjects.

\section{Measures}

We asked respondents about their unwanted sexual experiences, both those that had occurred in the past 12 months and those that had occurred since age 14, using five yes or no items adapted from scales developed by Koss and colleagues ${ }^{39}$ and Straus and colleagues. ${ }^{40}$ The first item, regarding attempted rape, read: "Someone tried to make me have sex by using threats, arguments or physical force, but this did not happen." (Sex was defined in the survey instructions as referring to vaginal, oral or anal sex.) The next three items addressed rape and asked whether the subject had ever been forced to have sex through physical force; through verbal pressure; or while being unable to resist because of the effects of alcohol or other drugs. The final item inquired if the subject had experienced any other type of unwanted sexual contact, such as touching or forced kisses.

For use in analyses of risk factors for victimization, we created a trichotomous dependent variable specifying the most severe type of unwanted sexual experience, if any, that the respondent had experienced since age 14. The mutually exclusive categories indicated that the subject reported having experienced attempted rape or rape; less severe forms of sexual victimization; or no unwanted sexual experience.

The independent variables included two measures of childhood experience with violence. Subjects were classified as having experienced childhood sexual abuse if they responded affirmatively to at least one of the following questions: "Before age 14, did anyone make you have sex against your will?" and "Before age 14, did you ever have any other form of unwanted sexual experience, such as forced kisses, touching, etc.?" They were considered to have witnessed domestic violence if they responded affirmatively to the question, "Before age 14, did you at some point witness physical violence between your parents or other people who raised you (e.g., hitting, slapping)?"

We also included several dichotomous socioeconomic and demographic variables in our analyses. Parental education was categorized as low if the subject's parent or guardian with the highest level of education had had no more than a secondary school education, or had not com-

*This procedure utilizes information on the order of the three sexual vic timization categories (i.e., the greater severity of rape or attempted rape as compared with other types of unwanted sexual contact). The ordered logit method assumes that the odds ratio is constant for all categories; score tests failed to reject the proportional odds assumption for all models that were estimated $(p<.05)$.

†To minimize loss of information, instances of missing data for the independent variables were addressed by imputing measures of central tendency (median for age; modal category for other variables). Twenty-nine cases were imputed for the variable regarding whether the subject had ever had sexual intercourse. For the other variables, the number of observations with imputations ranged from two cases for low parental education to 13 cases for witnessing domestic violence. pleted advanced technical schooling. Religious participation was defined as having attended religious services at least several times per year at age 14 . Additional variables indicated whether the subject had ever had voluntary sexual intercourse (vaginal or anal), whether the subject had resided in Santiago or another large urban area at age 14, and whether the subject's primary place of residence during the college years had been the parental home. The subject's age in years, coded as a continuous variable, was included in all analyses to control for length of exposure to the risk of victimization.

Finally, the survey included items assessing rape myth beliefs adapted from scales developed by Lanier and Elliott ${ }^{41}$ and by Barnett and Feild. ${ }^{42}$

\section{Statistical Analysis}

We generated means and cross-tabulations for the independent variables, as well as descriptive statistics on the prevalence of sexual victimization, the degree of rape myth acceptance and the context of the most severe incident reported per subject.

Next, we used ordered logit models to examine factors associated with sexual victimization since age 14, using Proc Logistic in SAS, Version 9.1. ${ }^{*}$ We conducted multivariate analyses by building sequential models: The socioeconomic and demographic variables were included first, and the witnessing of domestic violence and childhood sexual abuse variables were added next, one at a time. Rape myth acceptance was examined only for descriptive purposes and not included in multivariate analyses, because this variable was measured on the survey date, subsequent to any victimization experiences; thus, it is impossible to determine whether subscribing to rape myths increases vulnerability to victimization.

\section{RESULTS \\ Participants}

Subjects ranged in age from 18 to 30 years, with a median of 19 , reflecting students' tendency to take general education courses early in their studies (Table 1). ${ }^{\dagger}$ Thirty-one percent came from homes with low parental education; 79\% reported living mainly with their parents during their col-

\begin{tabular}{|c|c|}
\hline Characteristic & $\begin{array}{l}\text { Median or \% } \\
(\mathrm{N}=455)\end{array}$ \\
\hline \multicolumn{2}{|l|}{ MEDIAN } \\
\hline Age & 19.0 \\
\hline \multicolumn{2}{|l|}{ PERCENTAGES } \\
\hline Low parental education & 30.5 \\
\hline Religious participation† & 58.7 \\
\hline Residence with parentsł & 78.7 \\
\hline Ever had sex & 61.8 \\
\hline Lived in large city $†$ & 78.0 \\
\hline Witnessed domestic violence§ & 35.2 \\
\hline Sexually abused§ & 20.9 \\
\hline
\end{tabular}


lege years, consistent with the norm for college students in Santiago (with the exception of students coming from other parts of the country).

Thirty-five percent of the young women reported having witnessed domestic violence before age 14, and $21 \%$ reported having experienced some form of sexual abuse before age 14. Subjects whose parents had low levels of education were more likely than those with better educated parents to have witnessed domestic violence (45\% vs 31\%) and to have been sexually abused (29\% vs $17 \%$ ) before age 14 ( $\mathrm{p}<.01$; not shown). The prevalence of childhood sexual abuse was $25 \%$ among subjects who had witnessed domestic violence and 19\% among those who had not ( $\mathrm{p}=.11$ ).

\section{Prevalence and Contexts of Sexual Victimization}

Overall, $2 \%$ of subjects reported that they had been physically forced to have sex (on one or more occasions) since age $14,4 \%$ had been verbally pressured into having sex, and $7 \%$ reported that someone had had sex with them while they were under the influence of alcohol or other drugs and unable to stop what was happening (Table 2). In addition, $11 \%$ of respondents reported an attempted rape, and 25\% reported another type of forced sexual contact.

Subjects could report more than one type of sexual victimization, if applicable. When we classified subjects according to the most severe type of sexual victimization they reported having experienced since age 14 , we found that rape was the most severe event for $9 \%$, attempted rape for $6 \%$ and another form of unwanted sexual contact for $16 \%$. In total, $31 \%$ of subjects reported having experienced at least one type of sexual victimization since age 14 , and $17 \%$ reported having experienced at least one event in the past 12 months alone.

Other survey items explored the context of the most severe incident of sexual victimization subjects had experienced since age $14 .{ }^{*}$ Both the victim and the perpetrator had used alcohol or other drugs in $56 \%$ of rapes or attempted rapes and $24 \%$ of other incidents of unwanted sexual contact (not shown); the victim, but not the perpetrator, had used alcohol or other drugs in $6 \%$ of rapes or attempted rapes and $2 \%$ of other incidents of unwanted sexual contact, and the perpetrator, but not the victim, had used alcohol or other drugs in $9 \%$ of rapes or attempted rapes and $18 \%$ of other incidents. Only $2 \%$ of rapes or attempted rapes, and none of the less severe sexual contacts, were reported to the police. The incidents most commonly occurred at the home of the subject or perpetrator (38\%), or at parties at a home (31\%). Most subjects identified the perpetrator of the most severe incident as someone they knew but who was not related: an acquaintance (28\%), friend ( $9 \%)$, casual date (13\%), or steady dating partner (27\%). Seven percent of the cases involved a family member and the remaining $17 \%$ a stranger.

*Approximately one-fifth of subjects did not complete these survey items; these cases were excluded in calculating the descriptive statistics in this paragraph.

\begin{tabular}{|c|c|c|}
\hline Measure & $\begin{array}{l}\text { Since age } 14 \\
(\mathrm{~N}=455)\end{array}$ & $\begin{array}{l}\text { Past } 12 \text { months } \\
(\mathrm{N}=430) \dagger\end{array}$ \\
\hline \multicolumn{3}{|l|}{ Experienced } \\
\hline \multicolumn{3}{|l|}{ Rape } \\
\hline Physical force & 2.0 & 0.9 \\
\hline Verbal pressure & 3.5 & 1.2 \\
\hline Alcohol/other drugs & 6.8 & 4.2 \\
\hline Attempted rape & 10.8 & 4.2 \\
\hline Other forced sexual contact & 25.1 & 12.8 \\
\hline \multicolumn{3}{|c|}{ Most severe form experienced } \\
\hline Rape & 9.4 & 5.6 \\
\hline Attempted rape & 6.2 & 2.1 \\
\hline Other forced sexual contact & 15.6 & 9.5 \\
\hline None & 68.8 & 82.8 \\
\hline Total & 100.0 & 100.0 \\
\hline
\end{tabular}

\section{Rape Myth Acceptance}

For six of the ten rape myth items, the proportion of women who agreed or strongly agreed was less than 4\% (Table 3). At the same time, substantial minorities of women subscribed to the other myths. For example, 28\% of respondents agreed or strongly agreed that "the degree of resistance that a woman presented should be the main factor in determining whether what happened was a rape," and $22 \%$ agreed or strongly agreed that "women often lie about having been raped." Ancillary analyses of the male sample (not shown) revealed that agreement with each rape myth was higher for men than for women; differences by sex were large and statistically significant.

\section{Bivariate and Multivariate Analyses}

In bivariate analyses, sexual victimization since age 14 was associated with low parental education, religious participation at age 14 , witnessing domestic violence, and childhood sexual abuse; the relationship with age approached

\section{TABLE 3. Percentage of subjects who agreed or strongly agreed with rape myths}

Statement

In most cases, when a woman is raped, she was looking for it.

Women provoke rape by their appearance or behavior. 1.1

A man can control his behavior regardless of how sexually excited he is. $t$

The degree of resistance that a woman presented should be the main factor in determining whether what happened was a rape.

86.4

If someone makes a rape charge two weeks after it happened, it probably was not a rape. $\quad 3.7$

Women often lie about having been raped.

21.5

If a woman goes to the home of her date, this means she is consenting to have sex.

2.0

If a woman fondles a man's genitals, this means she is consenting to have sex.

41.5

If a couple has had sex before, the man should be able to have sex when he wants to.

2.4

A man is justified in having sex if his partner agreed to but changed her mind at the last minute.

†Statement was reverse coded in analyses. Notes: Subjects were asked to indicate strong agreement, agreement, disagreement or strong disagreement with each statement. Surveys with responses missing on four or more statements were excluded. For surveys with responses missing on 1-3 statements, responses for the missing items were imputed using the mean of the subject's completed items, taking into account the reverse coding for the third item. Cronbach's alpha for the scale was 0.69 . 


\begin{tabular}{|c|c|c|c|c|c|}
\hline \multirow[t]{2}{*}{ Measure } & \multirow[t]{2}{*}{ Bivariate } & \multicolumn{4}{|l|}{ Multivariate } \\
\hline & & Model 1 & Model 2 & Model 3 & Model 4 \\
\hline Age & $1.08(0.99-1.17) \dagger$ & $1.07(0.98-1.17)$ & $1.07(0.98-1.17)$ & $1.02(0.93-1.12)$ & $1.02(0.92-1.12)$ \\
\hline Low parental education & $1.55(1.03-2.35)^{*}$ & $1.58(1.04-2.39)^{*}$ & $1.50(0.98-2.28) \dagger$ & $1.28(0.82-1.98)$ & $1.22(0.78-1.90)$ \\
\hline Religious participation $\neq$ & $0.65(0.44-0.96)^{*}$ & $0.65(0.44-0.96)^{*}$ & $0.65(0.44-0.96)^{*}$ & $0.69(0.46-1.05) \dagger$ & $0.69(0.46-1.05) \dagger$ \\
\hline Residence with parents§ & $0.71(0.45-1.12)$ & $0.70(0.44-1.11)$ & $0.72(0.45-1.15)$ & $0.70(0.43-1.15)$ & $0.72(0.44-1.19)$ \\
\hline Ever had sex & $1.41(0.94-2.13) \dagger$ & na & na & na & na \\
\hline Lived in large city $¥$ & $0.78(0.49-1.23)$ & na & na & na & na \\
\hline Witnessed domestic violencet† & $1.58(1.06-2.35)^{*}$ & na & $1.44(0.95-2.17) \dagger$ & na & $1.39(0.90-2.14)$ \\
\hline Sexually abusedtt & $5.51(3.50-8.68)^{* *}$ & na & na & $5.12(3.23-8.14)^{* *}$ & $5.09(3.20-8.09)^{* *}$ \\
\hline $\begin{array}{l}\log L \\
\chi^{2}(d f)\end{array}$ & & $\begin{array}{l}-373.96 \\
13.83(4)^{* *}\end{array}$ & $\begin{array}{l}-372.47 \\
16.80(5)^{* *}\end{array}$ & $\begin{array}{l}-349.10 \\
63.54(5)^{* *}\end{array}$ & $\begin{array}{l}-347.97 \\
\quad 65.80(6)^{* *}\end{array}$ \\
\hline
\end{tabular}

significance (Table 4). Residence in a large city was not associated with victimization in bivariate analyses, and having ever had sexual intercourse-the only available measure of consensual sex-was marginally significant; these two variables failed to attain marginal significance in preliminary multivariate regressions and were excluded from further analyses.*

In the first multivariate model, which included only socioeconomic and demographic characteristics, the odds of reporting sexual victimization since age 14 among respondents whose parents had low levels of education were 1.6 times the odds among respondents with more educated parents. Participation in religious services at age 14 was associated with reduced odds of sexual victimization (odds ratio, 0.7).

The relationship between witnessing domestic violence and victimization approached statistical significance in Model 2 (odds ratio, 1.4). Model 3 shows that subjects who reported childhood sexual abuse had odds of victimization 5.1 times those among their counterparts who did not report such violence. There was no association between witnessing domestic violence and sexual victimization when childhood sexual abuse was included (Model 4). In addition, the association between low parental education and victimization risk decreased in size and became only marginally significant when witnessing domestic violence was added (Model 2) and lost all significance when childhood sexual abuse was added (Models 3 and 4), suggesting that childhood experiences with violence act as a mediator between low socioeconomic status in the family of origin and subsequent sexual victimization.

In ancillary analyses, we re-estimated the models in Table 4 , excluding the eight cases in which a family member was identified as the perpetrator of the most severe incident of sexual victimization since age 14 . In these analyses, the odds ratios associated with childhood sexual abuse in Models 3 and 4 (not shown) were slightly smaller than the one reported in Table 4, suggesting that there was long-term abuse (i.e., abuse by a family member both before and after

*However, the variable on residence with parents was retained because it attained marginal significance in ancillary analyses of a subsample. age 14) in those cases. Further, the odds ratio associated with residence with parents during the college years approached significance in Model 1 (odds ratio, 0.7, 95\% confidence interval $0.4-1.1, \mathrm{p}=.10$ ), providing some evidence that this living arrangement during the college years is protective in the typical case-that is, when the home environment is free of assailants.

\section{DISCUSSION}

Numerous studies conducted in the 1980s and 1990s revealed a high prevalence of sexual victimization among female college students in the United States, spurring initiatives to address this issue. ${ }^{43}$ Sexual assault prevention and education programs were instituted in colleges across the country, in part due to a mandate that campuses receiving federal funding sponsor such programs. ${ }^{44}$ Evidence from the present study suggests the importance of initiating similar efforts in Chile: Thirty-one percent of the female respondents reported that they had experienced some form of sexual victimization since age 14 , and $17 \%$ had been victimized in the past 12 months alone.

Nine percent of female respondents reported having been raped since age 14 , a proportion that is lower than the $15 \%$ prevalence for the same time frame reported for U.S. college women using a similar definition of rape. ${ }^{45}$ A more recent national study of U.S. college students also found a rape prevalence of $15 \%$ since age 15 in female respondents. ${ }^{46}$ However, it should be noted that our sample, unlike the U.S. samples, was disproportionately composed of students in their first or second academic year. Caution is also required in international comparisons, as findings may be affected by cultural differences in various factors, including the propensity to disclose sexual victimization incidents to researchers. ${ }^{13}$ This propensity is likely to be comparatively low in a socially conservative country such as Chile.

\section{Rape Myth Acceptance and Assault Context}

The belief that men may demonstrate their love through violent behaviors is pervasive in Chilean society, creating an environment in which violence against women can thrive. ${ }^{4,47}$ National laws in Chile have both reflected and 
reinforced social conservatism and traditional gender-role norms: Divorce remained illegal until 2004, and legislation against sexual harassment in the workplace was not passed until 2005. Although only a small proportion (<4\%) of women in this study agreed with most of the rape myths that we presented to them, there was a relatively high level of acceptance of several myths, consistent with Chile's traditional gender norms; these findings may help inform education programs. In addition, ancillary analyses showed that rape myth acceptance was greater by large margins in male students. Although previous studies have yielded mixed findings regarding the relationship between women's rape myth acceptance and vulnerability to sexual victimization, ${ }^{18,20,48}$ acceptance of rape myths among men has been found to be a strong predictor of aggressive behavior. ${ }^{49,} 50$ Studies have shown that men's and women's rape myth acceptance can be reduced through prevention programs; however, thus far, favorable attitudinal changes have been short-lived. ${ }^{17,51}$

Consistent with findings for U.S. college students, ${ }^{36}$ substance use by the victim, perpetrator or both was involved in more than half of the instances of rape or attempted rape, suggesting that it would be beneficial for sexual assault prevention and risk-reduction programs in Chile to focus on substance use awareness. ${ }^{52}$ Our finding that the perpetrators of the most severe incident reported by respondents were mainly identified as acquaintances, dating partners or friends is also consistent with data on U.S. college students, ${ }^{36,53}$ as is our finding that rape is a highly underreported crime. ${ }^{45}$

\section{Risk and Protective Factors}

About one-fifth of respondents reported having experienced sexual abuse during childhood. This high prevalence points to a need for further public health attention to this issue in Chile, especially given the potentially serious immediate and long-term consequences of such abuse. Childhood sexual abuse was the strongest predictor of sexual victimization since age 14 in this study: The odds of victimization among women who reported childhood sexual abuse were approximately five times the odds among women who did not report such abuse. Witnessing domestic violence before age 14 was a weaker predictor: It had a marginally significant relationship with victimization in Model 2, but lost that relationship when childhood sexual abuse was added in Model 4. Low parental education was associated with elevated odds of sexual victimization since age 14 in Model 1, but the association decreased markedly in size and lost significance as the variables on childhood experiences with violence were added in Models 2-4. Although causal mechanisms cannot be inferred from the present analyses, these sequential models suggest that the greater vulnerability to sexual victimization among students from low socioeconomic backgrounds was related to their higher levels of childhood sexual abuse and witnessing of domestic violence.

Consistent with study findings documenting an association between religiosity and a broad range of beneficial outcomes for youth, ${ }^{29,30,32-34}$ we found reduced odds of sexual victimization among young women who had participated in religious activities to some degree at age 14, although the association was only marginally significant in Models 3 and 4. In addition, ancillary analyses (not shown) suggest a lower risk of sexual victimization among students who live primarily with their families while attending college. This may be due in part to higher levels of parental supervision and less opportunity for exposure to risk; there may also be unobserved differences in the characteristics and risk behaviors of students who live with versus without their parents. In either case, the findings suggest that it would be helpful to address safe living outside of the parental home in Chilean risk-reduction programs.

\section{Limitations and Conclusions}

Some limitations of this study should be noted. Although the sample was broad, it was not random and the study findings cannot be generalized to the full student body. The estimates of sexual assault prevalence are likely to be conservative, as victims of gender-based violence commonly underreport it because of such factors as denial, not interpreting victimization as such, recall error and social desirability bias. ${ }^{54,55}$ Similarly, childhood sexual abuse and witnessing domestic violence were also likely underreported, leading to underestimates of associations between these factors and subsequent sexual victimization. To the extent that the sizable number of eligible subjects who did not attend class on the day of survey administration were disproportionately higher-risk individuals, victimization prevalence may have been further underestimated.

This study provides the first data on prevalence of and risk factors for sexual victimization among female college students in Chile. Our findings indicate a need for additional public health attention to sexual violence in Chilean college campuses, through further research on prevalence and on risk factors for victimization and perpetration, and through the development of theory-based programs to prevent and respond to this problem.

\section{REFERENCES}

1. Larraín SH, Violencia puertas adentro: la mujer golpeada, Santiago, Chile: Editorial Universitaria, 1994.

2. Morrison AR and Orlando MB, Social and economic costs of domestic violence: Chile and Nicaragua, in: Morrison AR and Biehl ML, eds., Too Close to Home: Domestic Violence in the Americas, Washington, DC: InterAmerican Development Bank, 1999, pp. 51-80.

3. Urzúa R et al., eds., Detección y Análisis de la Prevalencia de la Violencia Intrafamiliar, Santiago, Chile: Servicio Nacional de la Mujer, 2002

4. Ceballo R et al., Domestic violence and women's mental health in Chile, Psychology of Women Quarterly, 2004, 28(4):298-308.

5. Rivera-Rivera L et al., Prevalence and determinants of male partner violence against Mexican women: a population-based study, Salud Pública de México, 2004, 46(2):113-121.

6. Flake DF, Individual, family and community risk markers for domestic violence in Peru, Violence Against Women, 2005, 11(3):353-373.

7. García-Moreno et al., WHO Multi-Country Study on Women's Health and Domestic Violence Against Women, Geneva: World Health Organization (WHO), 2005

8. Krugman S, Mata L and Krugman R, Sexual abuse and corporal pun- 
ishment during childhood: a pilot retrospective survey of university students in Costa Rica, Pediatrics, 1992, 90(1):157-161.

9. Olsson A et al., Sexual abuse during childhood and adolescence among Nicaraguan men and women: a population-based anonymous survey, Child Abuse \& Neglect, 2000, 24(12):1579-1589.

10. Almeras D et al., Violencia contra la mujer en relación de pareja: América Latina y el Caribe, Serie Mujer y Desarrollo, Santiago, Chile: La Comisión Económica para América Latina, 2002, No. 40.

11. Rickert VI, Vaughan RD and Wiemann CM, Adolescent dating violence and date rape, Current Opinion in Obstetrics and Gynecology, 2002, 14(5):495-500.

12. Rickert VI, Vaughan RD and Wiemann CM, Violence against young women: implications for clinicians, Contemporary OB/GYN, 2003 , 48(2):30-45.

13. Krug EG et al., eds., World Report on Violence and Health, Geneva: WHO, 2002

14. Mirsky J, Beyond victims and villains: addressing sexual violence in the education sector, Panos Report, London: Panos Institute, 2003, No. 47.

15. International Institute for Higher Education in Latin America and the Caribbean (IESALC), Informe Sobre la Educación Superior en América Latina y el Caribe 2000-2005, Caracas, Venezuela: IESALC, 2006.

16. Rickert VI and Wiemann CM, Date rape among adolescents and young adults, Journal of Pediatric and Adolescent Gynecology, 1998, 11(4): $167-175$

17. Bachar K and Koss MP, From prevalence to prevention: closing the gap between what we know about rape and what we do, in: Renzetti CM, Edleson JL and Bergen RK, eds., Sourcebook on Violence Against Women, Thousand Oaks, CA, USA: Sage, 2001, pp. 117-142.

18. Vézina J and Hébert M, Risk factors for victimization in romantic relationships of young women: a review of empirical studies and implications for prevention, Trauma, Violence, E Abuse, 2007, 8(1):33-66.

19. Koss MP and Dinero TE, Discriminant analysis of risk factors for sexual victimization among a national sample of college women, Journal of Consulting and Clinical Psychology, 1989, 57(2):242-250.

20. Himelein MJ, Risk factors for sexual victimization in dating: a longitudinal study of college women, Psychology of Women Quarterly, 1995, 19(1):31-48

21. Gidycz CA, Hanson K and Layman MJ, A prospective analysis of the relationships among sexual assault experiences: an extension of previous findings, Psychology of Women Quarterly, 1995, 19(1):5-29.

22. Browne A and Finkelhor D, Impact of child sexual abuse: a review of the research, Psychological Bulletin, 1986, 99(1):66-77.

23. Messman TL and Long PJ, Child sexual abuse and its relationship to revictimization in adult women: a review, Clinical Psychology Review, 1996, 16(5):397-420.

24. Finkelhor D, The international epidemiology of child sexual abuse, Child Abuse \& Neglect, 1994, 18(5):409-417.

25. Ferguson AG, How good is the evidence relating to the frequency of childhood sexual abuse and the impact such abuse has on the lives of adult survivors? Public Health, 1997, 111(6):387-391.

26. Kantor GK and Jasinski JL, Dynamics and risk factors in partner violence, in: Jasinski JL and Williams LM, eds., Partner Violence: A Comprehensive Review of 20 Years of Research, Thousand Oaks, CA, USA Sage Publications, 1998, pp. 1-43.

27. Gonzalez de Olarte E and Gavilano Llosa P, Does poverty cause domestic violence? some answers from Lima, in: Morrison AR and Loreto Biehl M, eds., Too Close to Home: Domestic Violence in the Americas, Washington, DC: Inter-American Development Bank, 1999, pp. 35-50.

28. Finkelhor D, Current information on the scope and nature of child sexual abuse, The Future of Children, 1994, 4(2):31-53.

29. Donahue MJ and Benson PL, Religion and the well-being of adolescents, Journal of Social Issues, 1995, 51(2):145-160.

30. Koenig HG, McCullough ME and Larson DB, Handbook of Religion and Health, New York: Oxford University Press, 2001.
31. Bahr JS et al., Family, religiosity, and the risk of adolescent drug use, Journal of Marriage and the Family, 1998, 60(4):979-992.

32. Makepeace JM, Social factor and victim-offender differences in courtship violence, Family Relations, 1987, 36(1):87-91.

33. Howard D, Qiu Y and Boekeloo B, Personal and social contextual correlates of adolescent dating violence, Journal of Adolescent Health, 2003, 33(1):9-17

34. Gover AR, Risky lifestyles and dating violence: a theoretical test of violent victimization, Journal of Criminal Justice, 2004, 32(2):171-180.

35. Wyatt GE, Newcomb MD and Riederle MH, Sexual Abuse and Consensual Sex: Women's Developmental Patterns and Outcomes, Newbury Park, CA, USA: Sage, 1993.

36. Abbey A et al., Alcohol and dating risk factors for sexual assault among college women, Psychology of Women Quarterly, 1996, 20(1):147169.

37. Bergman L, Dating violence among high school students, Social Work, 1992, 37(1):21-27.

38. Spencer GA and Bryant SA, Dating violence: a comparison of rural, suburban, and urban teens, Journal of Adolescent Health, 2000, 27(5): 302-305

39. Koss MP et al., The Sexual Experiences Survey: Short FormVictimization, Tucson, AZ, USA: University of Arizona, 2006.

40. Straus MA, Hamby SL and Warren WL, The Conflict Tactics Scales Handbook: Revised Conflict Tactics Scale (CTS2) and CTS: Parent-Child Version (CTSPC), Los Angeles, CA, USA: Western Psychological Services, 2003

41. Lanier AA and Elliott MN, A new instrument for the evaluation of a date rape prevention program, Journal of College Student Development, 1997, 38(6):673-676

42. Barnett NJ and Feild HS, Sex differences in university students' attitudes toward rape, Journal of College Student Personnel, 1977, 18(2):9396.

43. Rozee PD and Koss MP, Rape: a century of resistance, Psychology of Women Quarterly, 2001, 25(4):295-311.

44. National Association of Student Personnel Administrators (NASPA), Complying with the Final Regulations: The Student Right-to-Know and Campus Security Act, Washington, DC: NASPA, 1994.

45. Koss MP, Gidycz CA and Wisniewski N, The scope of rape: incidence and prevalence of sexual aggression and victimization in a national sample of higher education students, Journal of Consulting and Clinical Psychology, 1987, 55(2):162-170.

46. Brener ND et al., Forced sexual intercourse and associated healthrisk behaviors among female college students in the United States, Journal of Consulting and Clinical Psychology, 1999, 67(2):252-259.

47. McWhirter PT, La violencia privada: domestic violence in Chile, American Psychologist, 1999, 54(1):37-40.

48. Muehlenhard CL and Linton MA, Date rape and sexual aggression in dating situations: incidence and risk factors, Journal of Counseling Psychology, 1987, 34(2):186-196.

49. Malamuth NM, Factors associated with rape as predictors of laboratory aggression against women, Journal of Personality and Social Psychology, 1983, 45(2):432-442.

50. Craig ME, Coercive sexuality in dating relationships: a situational model, Clinical Psychology Review, 1990, 10(4):395-423.

51. Breitenbecher $\mathrm{KH}$, Sexual assault on college campuses: Is an ounce of prevention enough? Applied and Preventive Psychology, 2000, 9(1):23-52.

52. Ullman SE, A critical review of field studies on the link of alcohol and adult sexual assault in women, Aggression and Violent Behavior, 2003, 8(5):471-486.

53. Koss MP, Hidden rape: sexual aggression and victimization in a national sample of students in higher education, in: Odem ME and ClayWarner J, eds., Confronting Rape and Sexual Assault, Wilmington, DE, USA: Scholarly Resources, 1998, pp. 51-70. 
54. Koss MP et al., No Safe Haven: Male Violence Against Women at Home, at Work and in the Community, Washington, DC: American Psychological Association, 1994.

55. Lewis SF and Fremouw W, Dating violence: a critical review of the literature, Clinical Psychology Review, 2001, 21(1):105-127.

\section{RESUMEN}

Contexto: A la fecha, ningún estudio cuantitativo ha examinado la prevalencia o factores correlacionados con la violencia sexual entre estudiantes universitarias en Chile.

Métodos: Se administró una encuesta anónima con preguntas sobre violencia basada en género, características demográficas y socioeconómicas, y experiencias de violencia en la niñez a estudiantes de una importante universidad pública en Santiago. Se generó un conjunto de estadísticas descriptivas para determinar la prevalencia y contexto de la victimización sexual experimentada por estudiantes mujeres; y los factores de riesgo asociados se identificaron usando modelos logit ordenados. Resultados: Nueve por ciento de las mujeres encuestadas reportaron que la forma más severa de contacto sexual no deseado que habían experimentado desde los 14 años era la violación; $6 \%$ indicó intención de violación y 16\% otra forma de victimización sexual. Diecisiete por ciento de las encuestadas reportaron haber experimentado alguna forma de contacto sexual no deseado en los pasados 12 meses. El alcohol u otras drogas habían sido utilizados en la mayoría de los casos de violación o intento de violación: en $56 \%$ de los casos, tanto la víctima como su atacante usaron alcohol u otras drogas; y en 6\%, sólo lo usó la víctima y en 9\%, sólo el atacante. En los modelos secuenciales, los factores asociados con una mayor probabilidad de victimización incluyeron una baja educación de los padres (Modelo 1) y el abuso sexual en la niñez (Modelos 3 y 4); la asociación entre haber presenciado la violencia doméstica y la victimización alcanzó una significancia marginal (Modelo 2). El haber asistido a servicios religiosos durante la adolescencia estuvo asociado con menores probabilidades de victimización (Modelos 1 y2). Solamente el abuso sexual en la niñez fue de significancia estadística cuando todas las variables fueron incluidas.

Conclusiones: Una proporción sustancial de mujeres jóvenes en la muestra reportaron experiencias de violación, intento de violación u otras formas de contacto sexual forzado, indicando la necesidad de una mayor atención a este problema de salud pública en Chile.

\section{RÉSUMÉ}

Contexte: À ce jour, aucune étude ne s'est penchée quantitativement sur la prévalence ou les corrélats de la violence sexuel- le dans la population étudiante universitaire du Chili.

Méthodes: Une enquête anonyme composée de questions sur la violence basée sur le genre, les caractéristiques sociodémographiques et l'expérience de la violence pendant l'enfance a été menée auprès des étudiants d'une grande université chilienne à Santiago. Des statistiques descriptives ont été produites afin de déterminer la prévalence et le contexte de la victimisation sexuelle des étudiantes, tandis que des modèles logistiques ordonnés permettaient d'identifier les facteurs de risque associés. Résultats: Neuf pour cent des sujets ont déclaré que la forme la plus grave de contact sexuel non désiré qu'elles avaient subie depuis l'âge de 14 ans était le viol; 6\% ont indiqué la tentative de viol et $16 \%$, une autre forme de victimisation sexuelle. Dixsept pour cent ont déclaré avoir subi une forme ou l'autre de contact sexuel non désiré durant les 12 derniers mois seulement. La consommation d'alcool ou d'autres drogues était intervenue dans la plupart des cas de viol ou de tentative de viol, par la victime (6\%), l'auteur de l'acte (9\%) ou les deux (56\%). Dans quatre modèles séquentiels, les facteurs associés aux probabilités accrues de victimisation se sont avérés le faible niveau d'instruction des parents (Modèle 1) et les sévices sexuels subis pendant l'enfance (Modèles 3 et 4); l'association entre le fait d'avoir été témoin de violences conjugales et la victimisation est marginalement significative (Modèle 2). La fréquentation de services religieux durant l'adolescence s'est révélée associée à une moindre probabilité de victimisation (Modèles 1 et 2). Toutes variables confondues, seuls les sévices sexuels subis pendant l'enfance sont associés à la victimization.

Conclusions: Une proportion substantielle de jeunes femmes de l'échantillon ont déclaré avoir subi un viol, une tentative de viol ou d'autres formes de contact sexuel forcé, laissant entendre la nécessité d'une plus grande attention à ce problème de santé publique au Chili.

\section{Acknowledgments}

Partial support for this study was provided by the Center for Latin American Studies at Columbia University. The authors thank Vaughn Rickert for helpful suggestions on the study design and survey instrument, Sarah Ullman for valuable comments on an earlier draft of this article, and Zhenxiang Zhao and Ramona Krauss for skillful research assistance. The study also benefited from the authors' discussions with participants at seminars presented at the University of Chile School of Medicine and Department of Social Sciences (Santiago, August 2006), and at a poster session at the annual meeting of the American Public Health Association, Boston, MA, USA, Nov. 4-8, 2006.

Author contact: $j$ lehrer1@gmail.com 